\title{
KMT2B wt Allele
}

National Cancer Institute

\section{Source}

National Cancer Institute. KMT2B wt Allele. NCI Thesaurus. Code C115963.

Human KMT2B wild-type allele is located in the vicinity of 19q13.1 and is approximately

$21 \mathrm{~kb}$ in length. This allele, which encodes histone-lysine N-methyltransferase 2B protein, plays a role in both lysine methylation and the positive regulation of gene transcription. 